
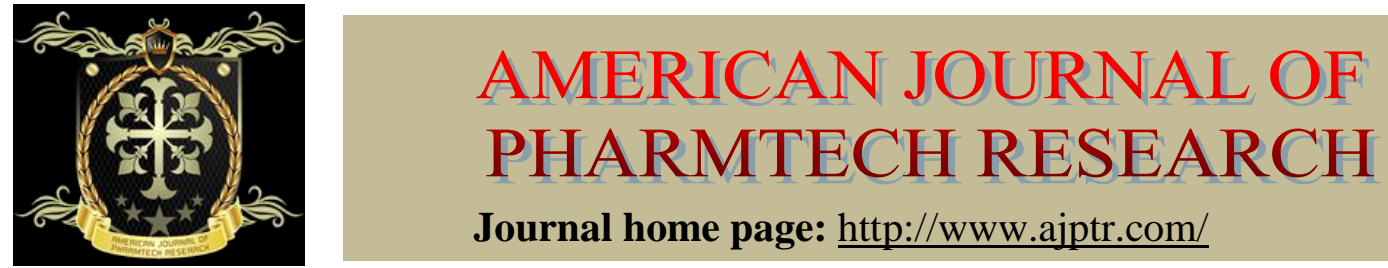

Journal home page: http://www.ajptr.com/

\title{
Optimization of Parameters for the Production of Protease using Aspergillus Flavus by Solid State Fermentation
}

\author{
Praveen Kumar Dasari* \\ Mother Teresa Pharmacy College, Sathupally, Telangana-507303, India.
}

\section{ABSTRACT}

The present work deals with the optimization and production Protease by Artocarpus heterophyllus as substrate in a solid state fermentation using microorganism Aspergillus flavus. Proteases are large and complex group of enzymes that plays a vital role in nutritional and regulatory activities. Proteases are essential for physiological functions in living organisms; they help in breakdown of protein food materials into amino acids, which the body can use for energy, and also play a vital role in essential processes, such as blood clotting, cell division. Solid-state fermentation is defined as a process that occurs on a non-soluble material that acts both as support and a source of nutrients, with a reduced among of water, under the action of fermenting agent. Protease enzyme production conditions like incubation time, incubation temperature, $\mathrm{pH}$, inoculum level and moisture content were optimized. The fermentation time of $72 \mathrm{hrs}$ and the temperature of $38^{\circ} \mathrm{C}, \mathrm{pH}$ 5 , inoculum level of $20 \% \mathrm{v} / \mathrm{w}$ and moisture content of $70 \% \mathrm{v} / \mathrm{w}$ were observed optimum for the production of Protease. Different carbon sources were screened for their influence on enzyme yield; they are glucose, sucrose, fructose and lactose used as supplements. Among these supplements sucrose gave better yield. $0.4 \% \mathrm{w} / \mathrm{w}$ of potassium nitrate as nitrogen source was observed optimum for the production of Protease.

Keywords: Artocarpus heterophyllus, Aspergillus flavus, Solid-state fermentation. 


\section{INTRODUCTION}

Proteases are large and complex group of enzymes that plays a vital role in nutritional and regulatory activities. Proteases are essential for physiological functions in living organisms; they help in breakdown of protein food materials into amino acids, which the body can use for energy, and also play a vital role in essential processes, such as blood clotting, cell division. Protease enzymes are found in a wide diversity of sources such as plants, animals and microorganisms but they are mainly produced by bacteria and fungi. Microbial proteases are deteriorating enzymes, which catalyze the total hydrolysis of proteins ${ }^{1,2}$. These are the most important industrial enzymes about $60 \%$ of the total enzymes market in the world and account for approximately $40 \%$ of the total worldwide enzyme sale ${ }^{3,4}$. Protease enzymes are majorly used in food industries, leather, meat processing, cheese making, detergents, silver recovery from photographic film, production of digestive and certain medical treatments of inflammation and virulent wounds. Proteases are also having medical and pharmaceutical applications. Microbial proteases are predominantly extracellular and can be secreted in the fermentation medium ${ }^{5,6}$.

Solid-state fermentation is defined as a process that occurs on a non-soluble material that acts both as support and a source of nutrients, with a reduced among of water, under the action of fermenting agent. Solid-state fermentation having many advantages like superior volumetric productivity, use of simpler machinery, use of inexpensive substrates, simpler downstream processing, and lower energy requirements when compared with submerged fermentation ${ }^{7,8}$. Fungi produce a wide variety of proteolytic enzymes than bacteria. They have a potential to grow under varying environmental conditions such as time, temperature, $\mathrm{pH}$ and moisture content etc, utilizing a wide variety of substrates as nutrients 9,10 . Nutrients can affect growth of the microorganisms either indirectly by affecting the availability of nutrients or directly by action on the cell surfaces ${ }^{11}$. The environmental conditions of the fermentation medium play an important role in the growth and metabolic production of a microbial growth. The purpose of this research was to produce protease from Aspergillus flavus using Artocarpus heterophyllus as a substrate under Solid-state fermentation.

\section{MATERIALS AND METHOD}

\section{Substrate:}

Artocarpus heterophyllus was collected from local market and dried naturally and powdered, packed and stored until further use.

Microorganism: 
Aspergillus flavus was used for the production of Protease enzyme using Artocarpus heterophyllus as substrate. Potato dextrose agar medium was used for the maintenance and sub culturing of the microorganism.

\section{Preparation of Inoculum:}

Streaking is done from the old cultures of Aspergillus flavus on pure potato dextrose agar slants and incubated them at $30^{\circ} \mathrm{C}$ for 3 days.

\section{Development of Inoculum:}

$10 \mathrm{ml}$ of sterile distilled water were added to the cells from 3 days old slant, from that $1 \mathrm{ml}$ of suspension containing approximately $10^{5}-10^{6} \mathrm{spores} / \mathrm{ml}$ were used as the inoculum to each flask.

\section{Fermentation condition:}

Solid-state fermentation was carried out in $250 \mathrm{ml}$ conical flask containing $10 \mathrm{~g}$ of substrate with $10 \mathrm{ml}$ of production medium (g/l). $\mathrm{KNO}_{3} 2.0, \mathrm{MgSO}_{4} .7 \mathrm{H}_{2} \mathrm{O} 0.5, \mathrm{~K}_{2} \mathrm{HPO}_{4} 1.0, \mathrm{ZnSO}_{4} .7 \mathrm{H}_{2} \mathrm{O} 0.437$, $\mathrm{FeSO}_{4} .7 \mathrm{H}_{2} \mathrm{O} 1.116, \mathrm{MnSO}_{4} .7 \mathrm{H}_{2} \mathrm{O} 0.203, \mathrm{pH} 5.0$ and it was autoclaved at $121^{\circ} \mathrm{C}$ for $20 \mathrm{~min}$. After sterilization, the flasks were inoculated with $1.0 \mathrm{ml}$ of spore solution $\left(10^{6} \mathrm{spores} / \mathrm{ml}\right)$ and incubated at $30^{\circ} \mathrm{C}$ for six days in an incubator shaker at $100 \mathrm{rpm}$. At the end of fermentation, cultures were extracted with $100 \mathrm{ml}$ of distilled water by shaking for $1 \mathrm{hr}$. The filtrate obtained was centrifuged at $8000 \mathrm{rpm}$ for $10 \mathrm{~min}$ at room temperature. The supernatant used as crude enzyme extract.

\section{Determination of Enzyme Activity:}

\section{Enzyme assay:}

Protease activity was determined according to the modified Anson's method. $1 \mathrm{ml}$ of the culture broth was taken in a $100 \mathrm{ml}$ conical flask and $1 \mathrm{ml}$ of $\mathrm{pH} 7.0$ phosphate buffer added. $1 \mathrm{ml}$ of the substrate (2\% Hammersten's casein $\mathrm{pH}$ 7.0) was added to the buffer enzyme solution and incubated at $37^{\circ} \mathrm{C}$ for 10 minutes in a water bath. At the end of 10 minutes, $10 \mathrm{ml}$ of $5 \mathrm{~N}$ Trichloroacetic acid solution was added to stop the reaction. The precipitated casein was filtered off and $5 \mathrm{ml}$ of the filtrate were taken in a test tube. To this filtrate $10 \mathrm{ml}$ of $0.5 \mathrm{~N} \mathrm{NaOH}$ solution and $3 \mathrm{ml}$ of folin ciocalteu reagent were added. Final readings were taken from spectrophotometer at $750 \mathrm{~nm}$. Blank samples were prepared by adding the Trichloroacetic acid solution before the addition of substrate. The effect of various factors like incubation time, temperature, inoculum size, $\mathrm{pH}$, moisture content, carbon source and nitrogen sources on the production of protease was studied.

\section{RESULTS AND DISCUSSION:}

Microbial proteases have a number of applications in food, leather, meat processing and cheese making industries. These are commercially used in domestic detergents for the digestion of 
pertinacious stains of fabrics. It has been described that the production of extracellular proteases are by different microorganisms can be strongly influenced with the culture conditions. So, it has become necessary to understand the nature of proteases and their catalytic potentiality under different conditions. To determine the effect of time on enzyme production, the medium incubate at different time intervals and the maximum Protease activity was observed at $72 \mathrm{hrs}$. After $72 \mathrm{hrs}$, it was decreased due to depletion of nutrient materials. Protease production at different time intervals is shown in the figure 1.

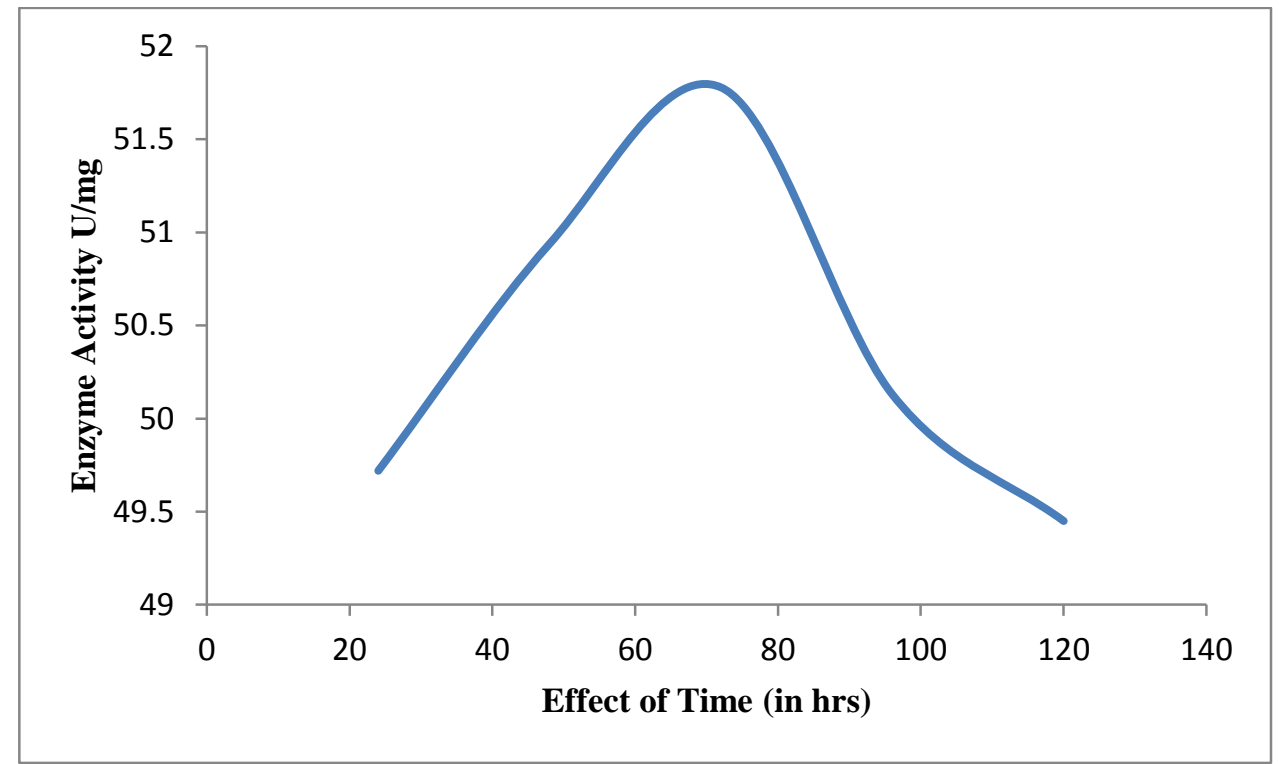

Figure 1: Effect of time on enzyme production

The temperature of the substrate is very critical in SSF as it ultimately affects the growth of the microorganism. The maximum amount of Protease was observed at $38^{\circ} \mathrm{c}$ temperature Figure .2.

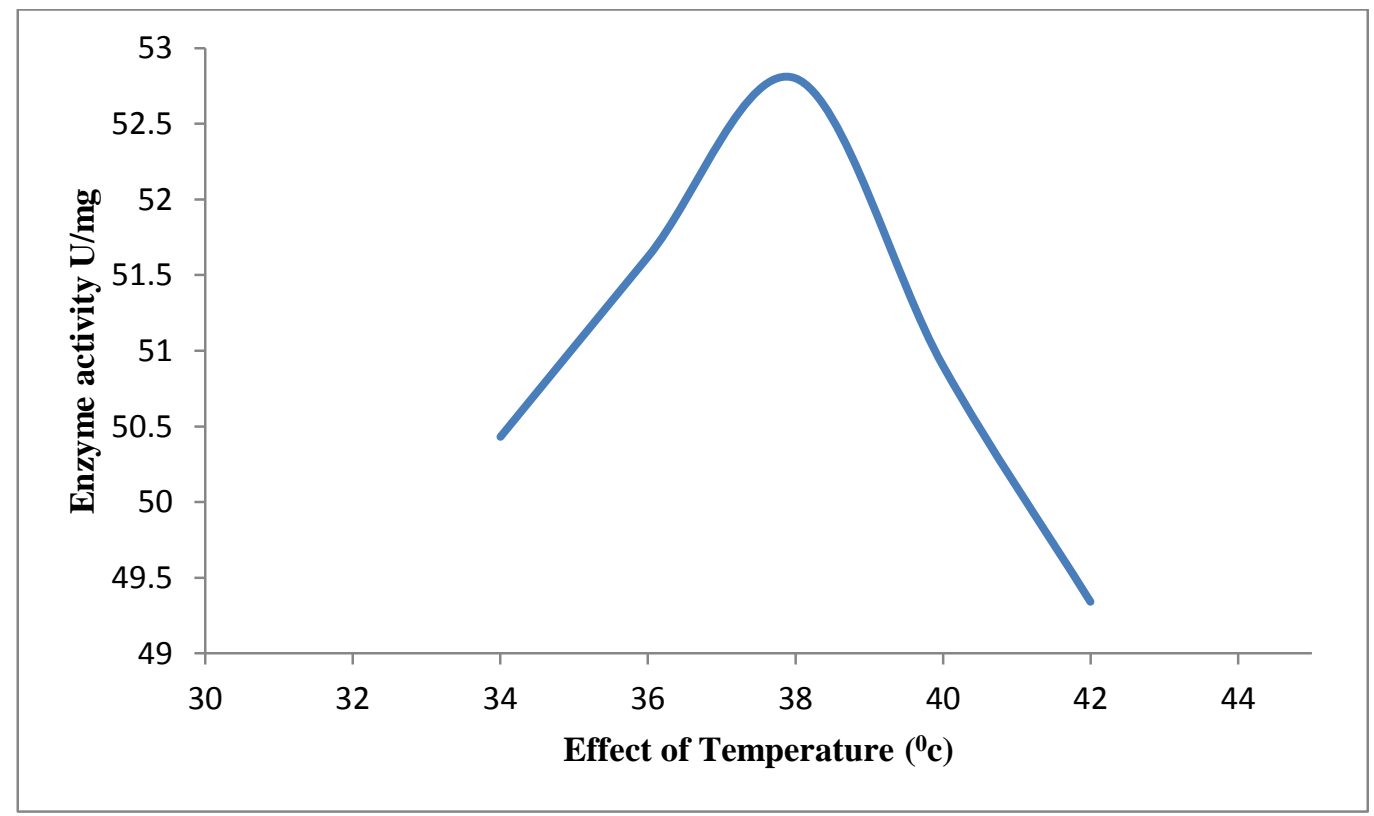

Figure 2: Effect of temperature on enzyme production 
To determine the effect of $\mathrm{pH}$, the bacterial nutrient medium was adjusted with different $\mathrm{pH}$ ranges 3, 4, 5, 6, and 7.0. The maximum production of Protease was recorded at $\mathrm{pH} 5$ figure 3.

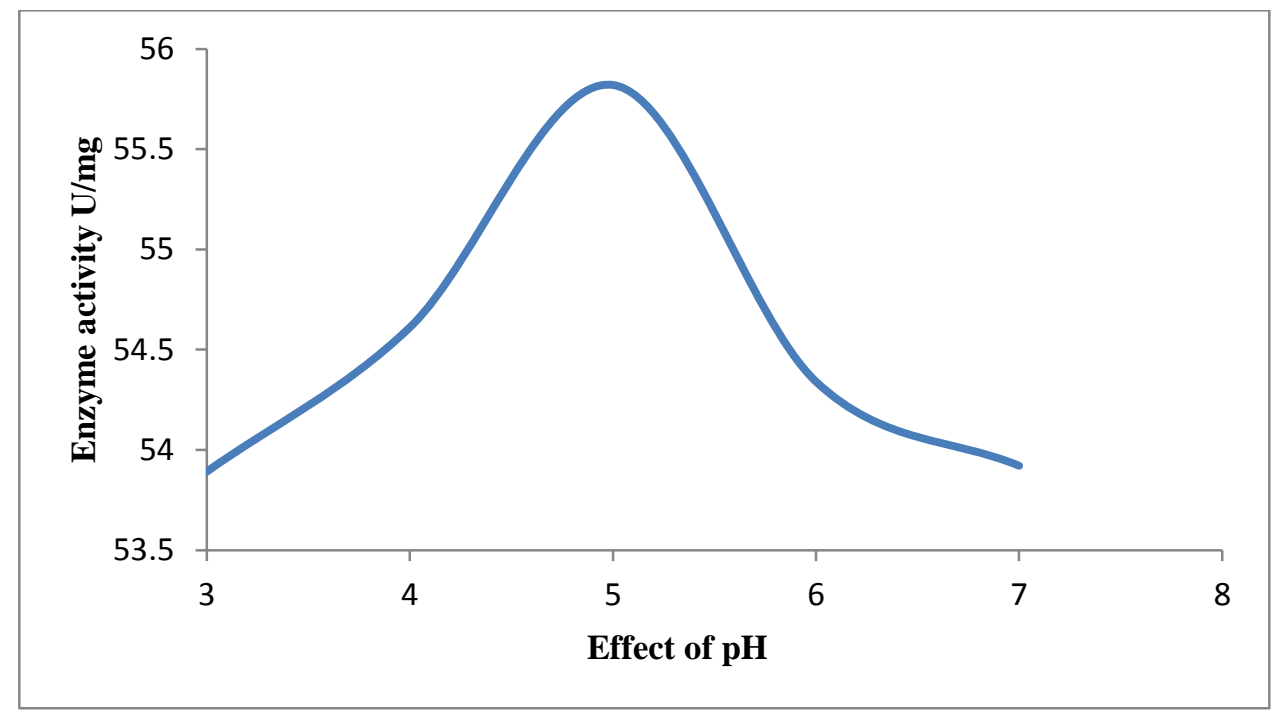

Figure 3: Effect of pH on enzyme production

Different inoculum levels were prepared for the production of enzyme 16\%, 18\%, 20\%, 22\%, 24\% v/w. The maximum enzyme production was observed at $20 \% \mathrm{v} / \mathrm{w}$ of inoculum figure 4.

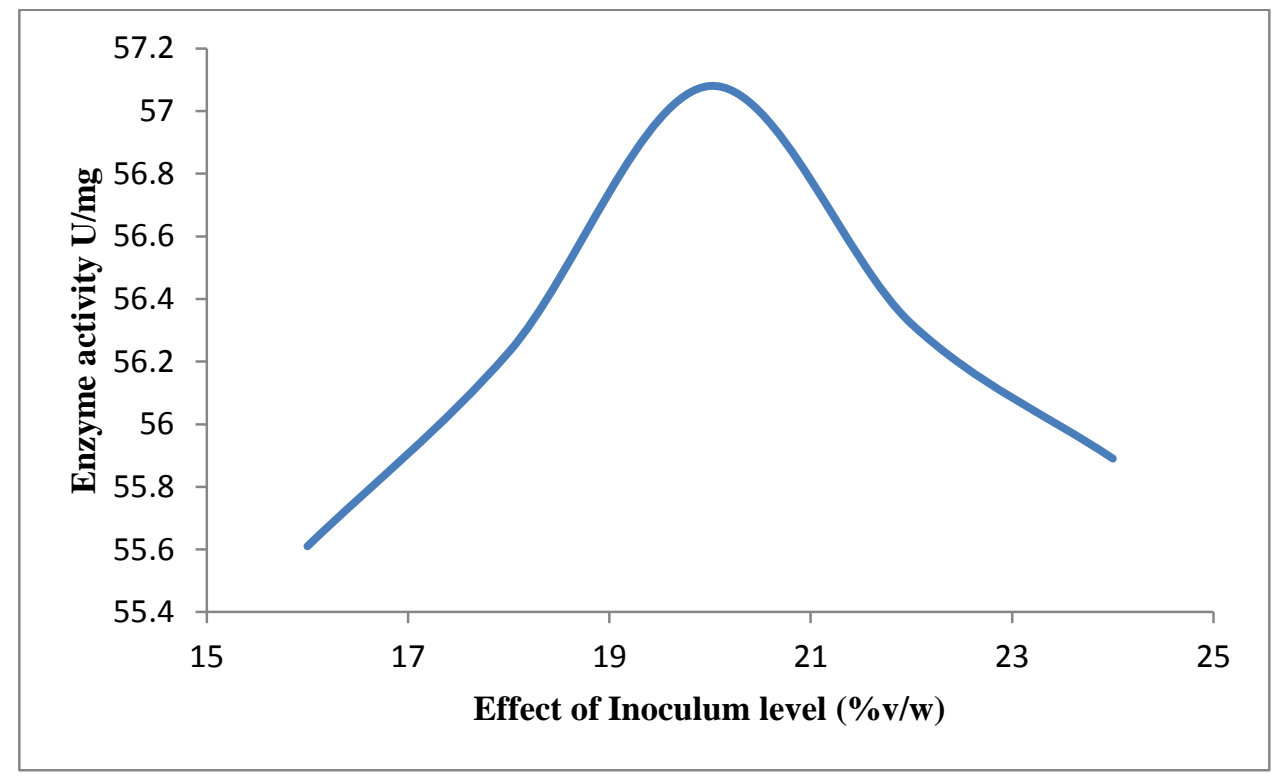

Figure 4: Effect of inoculum level on enzyme production

Moisture content is an important parameter for the production of enzymes in SSF. High moisture content results in decreased substrate porosity, which in turn prevents oxygen penetration. This may help bacterial contamination. Different moisture content 40\%, 50\%, 60\%, 70\%, 80\%, 90\%, and $100 \% \mathrm{v} / \mathrm{w}$ were taken in each conical flask. The maximum activity was observed at $70 \% \mathrm{v} / \mathrm{w}$ of the moisture content figure 5 . 


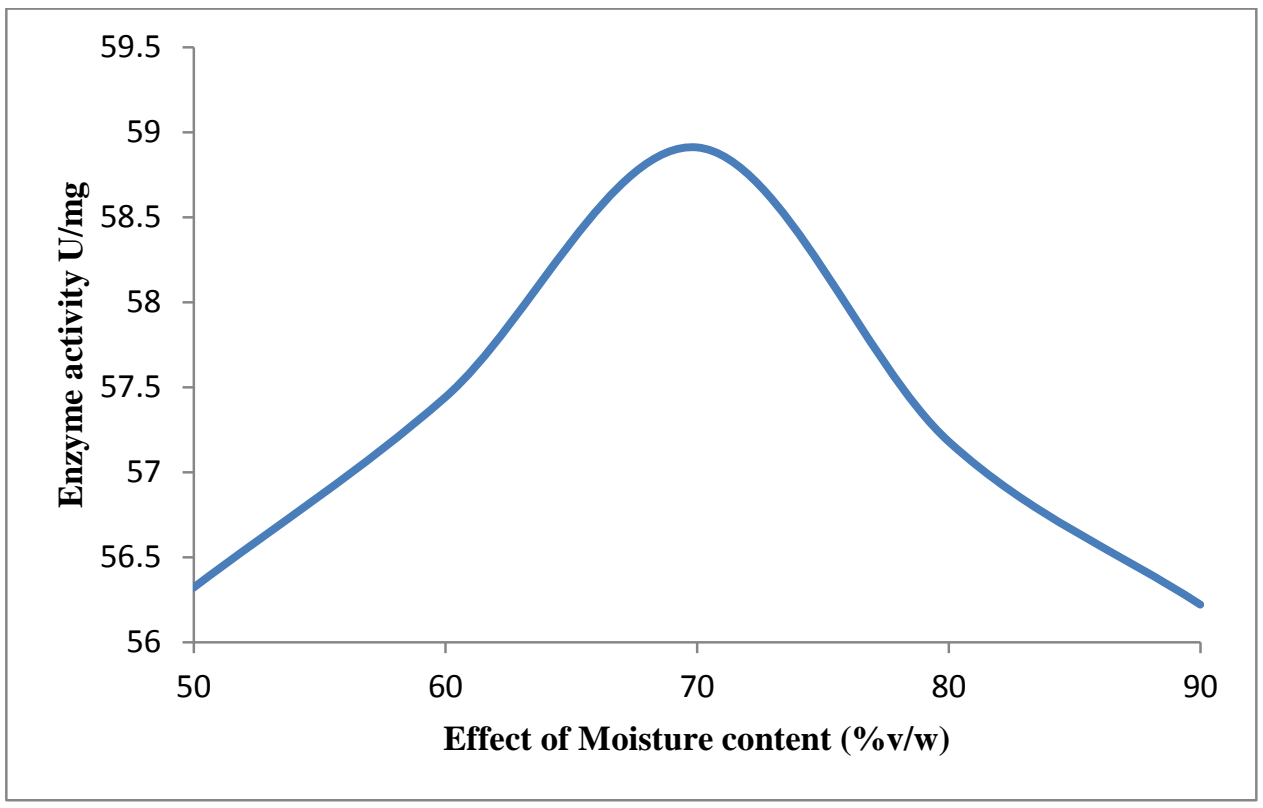

Figure 5: Effect of moisture content on enzyme production

Five different carbon sources were screened for the production of Protease enzyme which includes sucrose, maltose, glucose, fructose, and lactose. These are enriched with $\% \mathrm{w} / \mathrm{w}$. The results indicate that sucrose supplementation gave marginally improved enzyme than other supplementations. Production medium was prepared with different concentrations of sucrose like $1,2,3,4,5$ and $6 \% \mathrm{w} / \mathrm{w}$. The result indicates that maximum enzyme production was observed at $4 \% \mathrm{w} / \mathrm{w}$ of sucrose concentration figure 6.

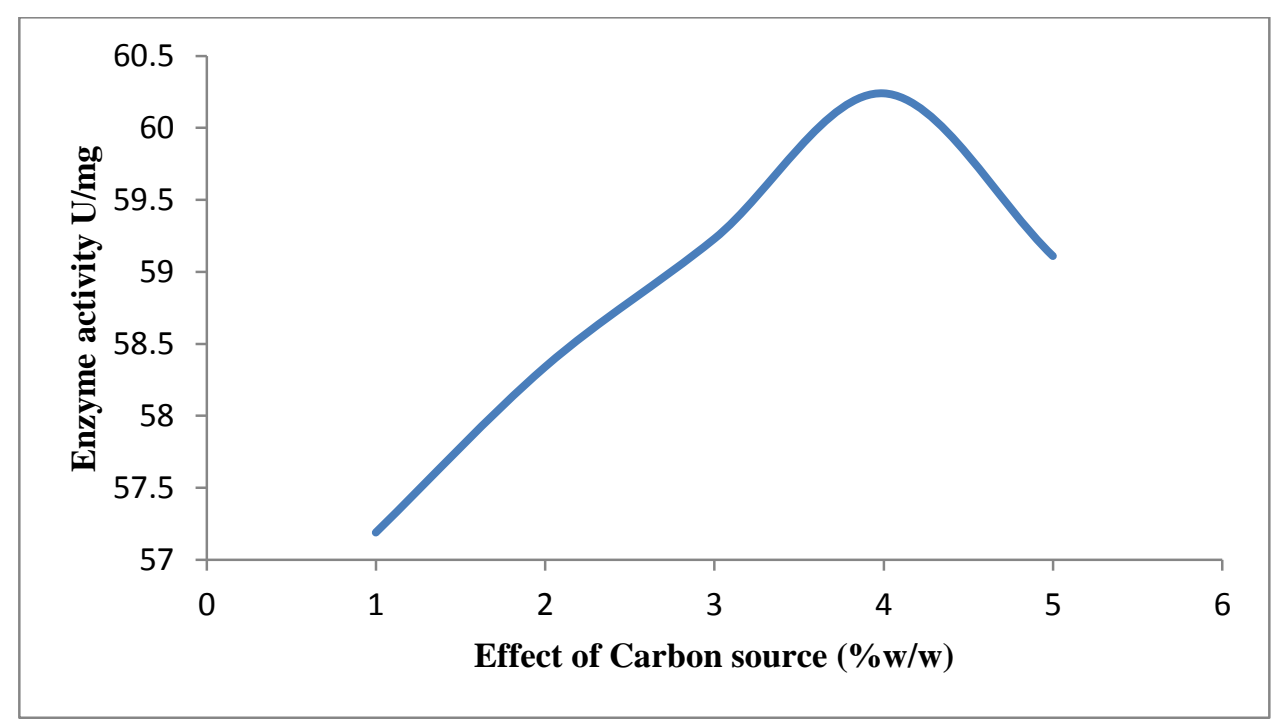

Figure 6: Effect of carbon source on enzyme production

To determine the effect of Protease on the production of enzyme, the production medium was prepared with different concentrations of potassium nitrate like $0.2 \%, 0.3 \%, 0.4 \%, 0.5 \%, 0.6 \%$ and $0.7 \% \mathrm{w} / \mathrm{w}$ were dispersed in $250 \mathrm{ml}$ conical flasks. The result indicates that maximum enzyme production was observed at $0.4 \% \mathrm{w} / \mathrm{w}$ concentration figure 7 . 


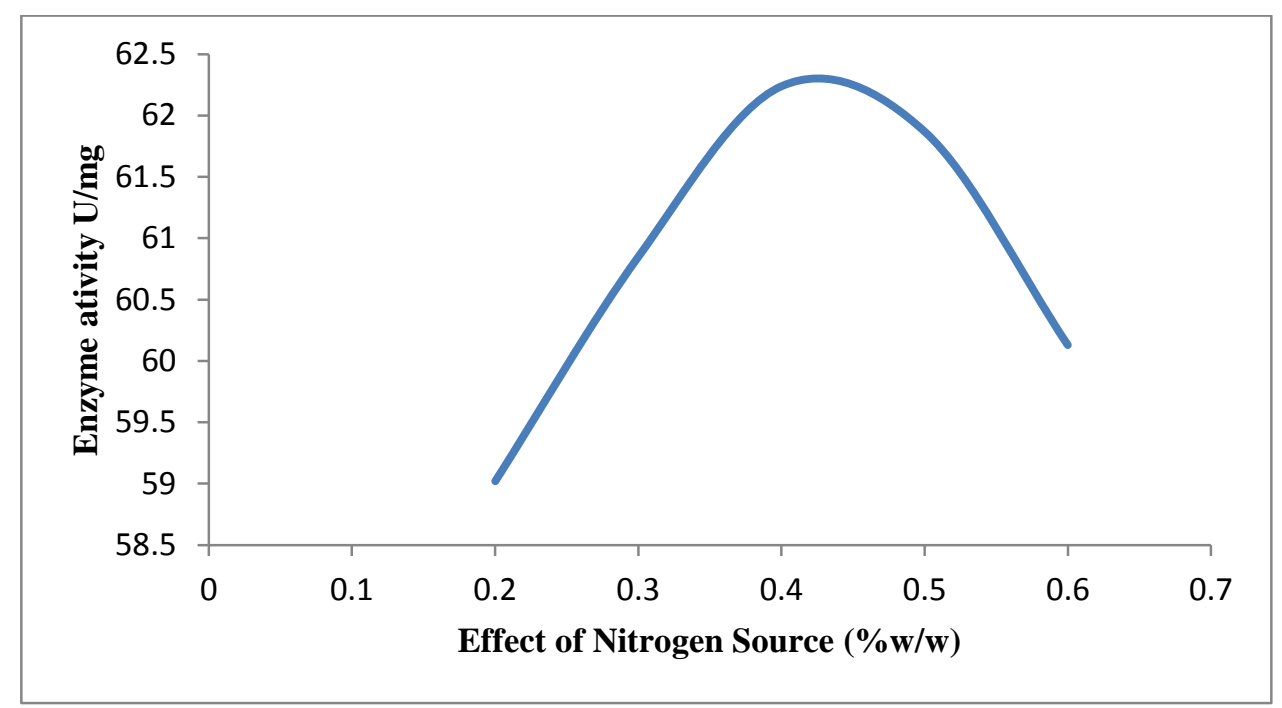

Figure 7: Effect of nitrogen source on enzyme production

\section{CONCLUSION:}

Finally we concluded that Aspergillus flavus is a promising agent for industrial application since it gave a significant Protease $(62.24 \mathrm{U} / \mathrm{mg})$ activity in Artocarpus heterophyllus under solid state fermentation. As Artocarpus heterophyllus is low cost substrate, easily available raw material and showing suitability for solid state cultivation of microbes, the lab-scale study on protease production from Artocarpus heterophyllus as major substrate might give the basic information of further development for large scale protease production.

\section{REFERENCES:}

1. Raju K, Jaya R. and Ayyanna C. Hydrolysis of casein by Bajara protease importance. Biotechnology Coming Decadea. 1994; 181: 55-70.

2. Haq I, Mukhtar ZA and Riaz N. Protease biosynthesis by mutant strain of Penicillium griseoroseum and cheese formation. Pakistan Journal Biological Science. 2004; 7: 14731476.

3. Chouyyok W, Wongmongkol N, Siwarungson N. and Prichnont S. Extraction of alkaline protease using an aqueous two-phase system from cell free Bacillus subtilis TISTR 25 fermentation broth. Process Biochemistry. 2005; 40: 3514-3518.

4. Godfrey T. and West S. Industrial Enzymology, 1996; 2nd ed., Macmillan Publishers Inc., New York.

5. Al-Shehri MA. Production and some properties of protease produced by Bacillus licheniformis isolated from Tihamet Aseer, Saudi Arabic. Pakistan Journal Biological Science. 2004; 7: 1631-1635. 
6. Barindra S, Debashish G, Malay S. and Joydeep M. Purification and characterization of a salt, solvent, detergent and bleach tolerant protease from a new gamma Proteobacterium isolated from the marine environment of the Sundarbans. Process Biochemistry. 2006; 41: 208-215.

7. Paranthaman R, Alagusundaram K. and Indhumathi J. Production of protease from rice mill wastes by Aspergillus niger in solid state fermentation. World Journal of Agricultural Science. 2009; 5(3): 308-312.

8. Verma OP, Kumari P, Shukla S, Singh A. Production of Alkaline Protease by Bacillus subtilis (MTCC7312) using Submerged Fermentation and Optimization of Process Parameters. European Journal of Experimental Biology. 2011; 1:124-129.

9. Lakshmi BKM, Ratnasri PV, Ambika Devi K, Hemalatha KPJ. Screening, optimization of production and partial characterization of alkaline protease from haloalkaliphilic Bacillus sp. Journal of Research Engineering Technology. 2014; 3:435- 443.

10. Haq, IU, Mukhtar H. and Umber H. Production of protease by Penicillium chrysogenum through optimization of environmental conditions. Journal of Agricultural Social Science. 2006; 2(1): 23-25.

11. Ellaiah P, Adinarayana K, Bhavani Y, Padmaja P. and Srinivasulu B. Optimization of process parameters for glucoamylase production under solid state fermentation by a newly isolated Aspergillus species. Process Biochemistry. 2002; 38: 615- 620.

\section{AJPTR is}

- $\quad$ Peer-reviewed

- bimonthly

- Rapid publication

Submit your manuscript at: editor@ajptr.com 